\title{
INSUKINE LIKE GROWTH FACTOR IN RELATION TO MACROSOMIA IN DIABETIC MOTHERS' BLOOD
}

\author{
Hesham Samy AbdElhamied pediatric professor Zagazig University, Ehab Mahmoud Rashied \\ pediatric professor Zagazig University, Esraa Ibrahim Mohamed pediatric resident Alahrar \\ Teaching Hospital, Zagazig (Egypt).
}

\section{ABSTRACT}

Purpose: The study aim was to assess the relation between maternal blood levels of insulin like growth factor $1 \&$ its relation to neonatal macrosomia.

Methods: 68 pregnant women was included in the study, divided into two groups as 34 women was diabetic (

TIDM, TIIDM or GDM) the other 34 was healthy women as control group. We obtain a venous blood sample ante-natally from each mother after consent, IGFI estimated on each sample.

Results: Between the two mother groups the significant difference was noted regarding the laboratory testing for both random blood sugar and for insulin like growth factor1. Mean random blood sugar in diabetic group was $241 \mathrm{mg} / \mathrm{dl}$ ranging from 130 to $400 \mathrm{mg} / \mathrm{dl}$. While; mean random blood sugar in control group was 109 $\mathrm{mg} / \mathrm{dl}$ ranging from 78 to $200 \mathrm{mg} / \mathrm{dl}$. With student $\mathrm{T}$ test 11.9 and $\mathrm{P}<0.001^{* *}$. Mean value of serum level of IGF1 in diabetic group founded to be $11.3 \mathrm{ng} / \mathrm{ml}$ with a range of 8.8 to $13 \mathrm{ng} / \mathrm{ml}$. In control group mean value of IGF1 $8.1 \mathrm{ng} / \mathrm{ml}$ ranging from 4.2 to $12.6 \mathrm{ng} / \mathrm{ml}$. with the student $\mathrm{T}$ test 7.1 and $\mathrm{P}$ value $<0.001 * *$

Conclusions: insulin like growth factor 1 was significantly higher in diabetic mothers blood which all give birth to macrosomic babies, IGF1 can be used as a predictive factor of fetal macrosomia.

Corresponding Author: Esraa Ibrahim Mohamed Ibrahim Tel.:01140630064

E.mail: soso_august1888@yahoo.com

\section{INTRODUCTION}

M acrosomia is the word for describing newborns with extremely high birth weight. It can only be diagnosed postnatally by measuring the baby's birth weight. Hence the diagnosis only confirmed after delivery of the baby it's not much valuable. Macrosomia can happen in up to $10 \%$ of living births ${ }^{[1]}$. The definition of fetal macrosomia, "large for gestational age" is neonatal birth weight $\geq 4$ $\mathrm{kg}$. It happens in $12 \%$ of deliveries of healthy pregnancy \& $15-45 \%$ of deliveries of gestational diabetes affected mothers ${ }^{[2]}$. The high incidence of macrosomia with gestational diabetes most probably due to raised insulin resistance. Also, large for gestational age babies are at increased risk of growing up as diabetics, hypertensive or obese adults ${ }^{[3]}$. Normal vaginal delivery of a macrosomic baby can be very risky for both mother \&infant and may cause injuries during birth. Antenatal diagnosis of fetal macrosomia is very hard. Suggesting signs \&symptoms: Polyhydramnios: increased amniotic fluid, Progressive fundus level. Diagnostic tests for macrosomia include: Antenatal ultrasound in 3rd trimester [4\&5]. Insulin like growth factor 1 "somatomedin C", is a protein manufactured in fibroblasts or other cells of mesenchymal origin, it has many mitogenic activities including induction of cell growth, division and differentiation. It also has an anabolic effect enhancing glucose and amino acid uptake by cells and decreasing protein breakdown ${ }^{[6]}$. Therefore come the need for a new specific test for diagnosis of neonatal macrosomia prenatally.

Aim of the study was to assess the relation between maternal blood levels of insulin like growth factor $1 \&$ its relation to neonatal macrosomia.

\section{MATERIAL AND METHODS}

This prospective case - control study was carried out on 2017. Zagazig University Hospitals delivery rooms of obstetrics and gynecology department. 68 pregnant women were enrolled in the study they were divided into 2 groups; the first group included 34 mothers who were suffering of (TIDM, TIIDM or GDM). The second group included 34 healthy pregnant females were assigned as control group all were matched with age.

Patients' inclusion Criteria:

. Insulin dependent type 1diabetic pregnant women.

Type II diabetic pregnant women.

Women with gestational DM.

Exclusion criteria:

Terminal illness.

Renal failure. 
All subjects included in this study were subjected to:

A) Complete history taking

B) Full clinical examination

C) investigations:-

1- Insulin like growth factor 1 level.

2- $\quad$ Random blood glucose level.

Also neonates of the mothers were subjected to: Full physical examination especially for birth weight measurement.

Statistical analysis: was performed using the Statistical Package for Social Sciences version 16.0 (SPSS for Windows 16.0, Inc., Chicago, IL, USA). Regarding quantitative parameters, the data was tested for normality using Shapiro wilk test that revealed that some data were normally distributed and others were not normally distributed. Parametric tests were used for normally distributed data. Results were expressed as Mean \pm SD. Independent samples student $t$ test was used to compare one variable in two groups. Pearson's correlation was used to correlate parametric variables. Linear regression and risk assessment tests were also used.

All $\mathrm{P}$ values were based on a 2-tailed distribution, and the responding $\mathrm{P}$ value: Non-significant (NS) difference if $\mathrm{P}>0.05$. Significant $(S)$ difference if $\mathrm{P}<0.05$. T

\section{RESULTS}

We studied the level of IGF1 in serum of 68 pregnant women right before delivery. 34 women were known diabetics (we didn't give much consideration to their type of diabetes since it wouldn't affect the laboratory data by any mean but we did take detailed history from each mother in order to get good insight about their glycemic control during pregnancy) and the rest were healthy pregnant women as a control group. The two groups were cohesive and have no significant difference according to age. According to statistical analysis the mean age was $32.7 \pm 5.8$ with T test value -0.06 and $\mathrm{p}$ value was 0.9 . (table1)

Between the two mother groups the significant difference was noted regarding the laboratory testing for both random blood sugar and for insulin like growth factor 1 (table2)

Mean random blood sugar in diabetic group was $241 \mathrm{mg} / \mathrm{dl}$ ranging from 130 to 400 $\mathrm{mg} / \mathrm{dl}$. While; mean random blood sugar in control group was $109 \mathrm{mg} / \mathrm{dl}$ ranging from 78 to $200 \mathrm{mg} / \mathrm{dl}$. With student T test 11.9 and $\mathrm{P}$ $<0.001 * *$

Mean value of serum level of IGF1 in diabetic group founded to be $11.3 \mathrm{ng} / \mathrm{ml}$ with a range of 8.8 to $13 \mathrm{ng} / \mathrm{ml}$. In control group mean value of IGF1 $8.1 \mathrm{ng} / \mathrm{ml}$ ranging from 4.2 to $12.6 \mathrm{ng} / \mathrm{ml}$. with the student T test 7.1 and $\mathrm{P}$ value $<0.001^{* *}$ (table2)

Gestational age according to our study varies in the two groups where in the control group the mean gestational age was 37.4 weeks ranging from 34 to 39 weeks of gestation $\mathrm{T}$ test -6.4 and $\mathrm{P}$ value $<0.001 * *$ with the fetal birth weight mean $2.8 \mathrm{~kg}$ varying from 2.3 to $3.4 \mathrm{~kg}$. While; in the case group the mean gestational age was 35 weeks with a mean fetal weight of $4.2 \mathrm{~kg}$ ranging from 3 to $4.9 \mathrm{~kg}$ (table3) (fig1). We found that with fetal macrosomia, babies are more likely to be delivered early with a mean gestational age of 35 weeks, (table3)

Table1: Age distribution between the mothers of the two studied groups.

\begin{tabular}{lllll}
\hline Variable & $\begin{array}{l}\text { Control mothers } \\
(\mathrm{n}=34)\end{array}$ & $\begin{array}{l}\text { Diabetic mothers } \\
(\mathrm{n}=34)\end{array}$ & $\begin{array}{l}\text { Student } \\
\mathrm{T} \text { test }\end{array}$ & $\mathrm{P}$ \\
\hline Age & & & \\
Mean $\pm S D$ & $32.7 \pm 5.8$ & $32.6 \pm 5.3$ & 0.06 & 0.9 \\
Range & $(25-45)$ & $(25-45)$ & \\
\hline $\begin{array}{l}\text { This table shows that there is no significant difference between Control mothers and diabetic } \\
\text { mothers as regard to age. }\end{array}$
\end{tabular}


Table2: Laboratory findings between the mothers of the two studied groups

\begin{tabular}{|c|c|c|c|c|}
\hline Variable & $\begin{array}{l}\text { Control mothers } \\
(\mathrm{n}=34)\end{array}$ & $\begin{array}{l}\text { Diabetic mothers } \\
(n=34)\end{array}$ & $\begin{array}{l}\text { Student } \\
\text { T test }\end{array}$ & $\bar{P}$ \\
\hline $\begin{array}{l}\text { RBS mg/dl } \\
\text { Mean } \pm S D \\
\text { Range }\end{array}$ & $\begin{array}{l}109.2 \pm 23.5 \\
(78-200)\end{array}$ & $\begin{array}{l}241.8 \pm 60.4 \\
(130-400)\end{array}$ & 11.9 & $<0.001 * *$ \\
\hline $\begin{array}{l}\text { IGF1 ng/ml } \\
\text { Mean } \pm S D \\
\text { Range }\end{array}$ & $\begin{array}{l}8.1 \pm 1.3 \\
(4.2-12.6)\end{array}$ & $\begin{array}{l}11.3 \pm 1.1 \\
(8.8-13)\end{array}$ & 7.1 & $<0.001 * *$ \\
\hline
\end{tabular}

This table shows that there is a significant difference between control mothers \& diabetic mothers as regard RBS and IGF1.

Table3: Gestational age and weight distribution between the fetuses of the two studied groups.

\begin{tabular}{lllll}
\hline Variable & $\begin{array}{l}\text { infant of Control } \\
\text { mothers } \\
(\mathrm{n}=34)\end{array}$ & $\begin{array}{l}\text { infant of Diabetic } \\
\text { mothers } \\
(\mathrm{n}=34)\end{array}$ & Student T test & $\mathrm{P}$ \\
\hline $\begin{array}{l}\text { Gestational age (Wks) } \\
\text { Mean } \pm S D\end{array}$ & & & -6.4 & $<0.001^{* *}$ \\
Range & $\begin{array}{l}37.9 \pm 1.3 \\
(34-40)\end{array}$ & $\begin{array}{l}35.1 \pm 2.1 \\
(32-39)\end{array}$ & 16.4 & $<0.001^{* *}$ \\
\hline Fetal weight(Kgs) & & & & \\
Mean $\pm S D$ & $2.8 \pm 0.3$ & $4.2 \pm 0.4$ & $(3-4.9)$ & \\
Range & $(2.3-3.4)$ & $(3)$ & & \\
\hline
\end{tabular}

This table shows that there is a significant difference between the Infant of Control mothers and Infant of Diabetic mothers as regard gestational age and fetal weight.

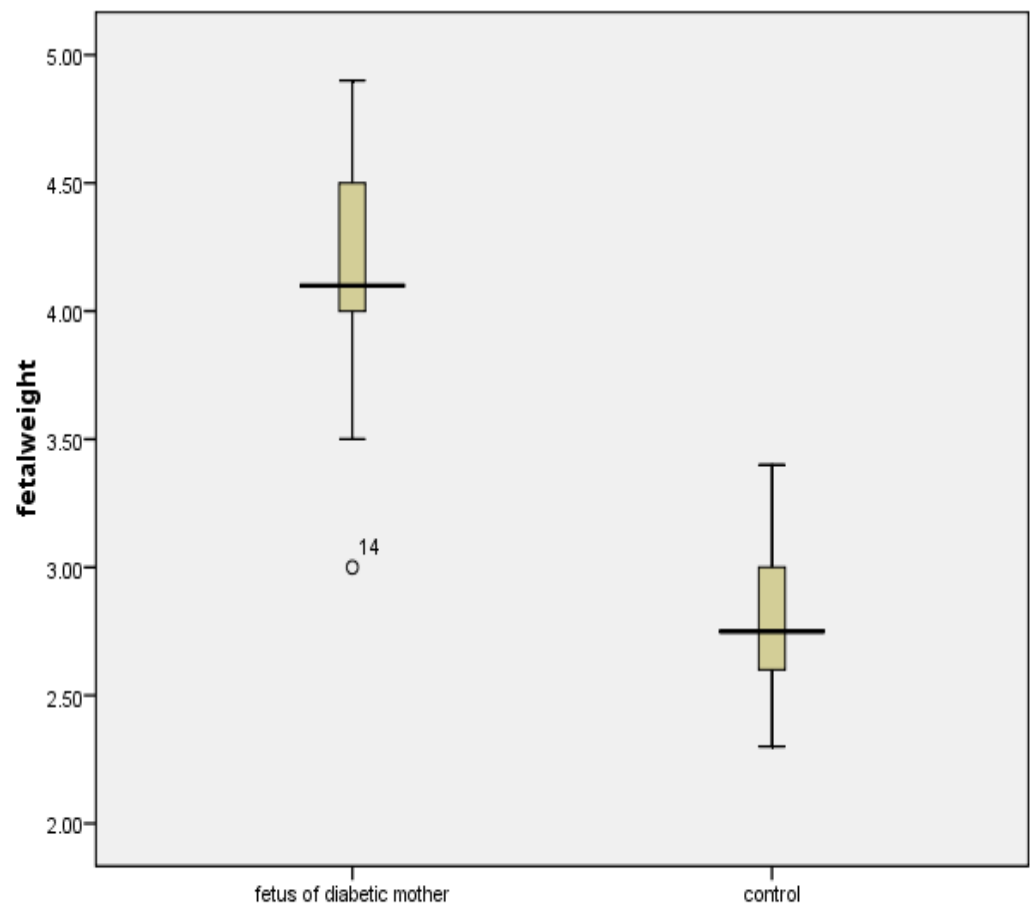

Figure 1, Box plot of the gestational age of the infants of the two studied groups. 


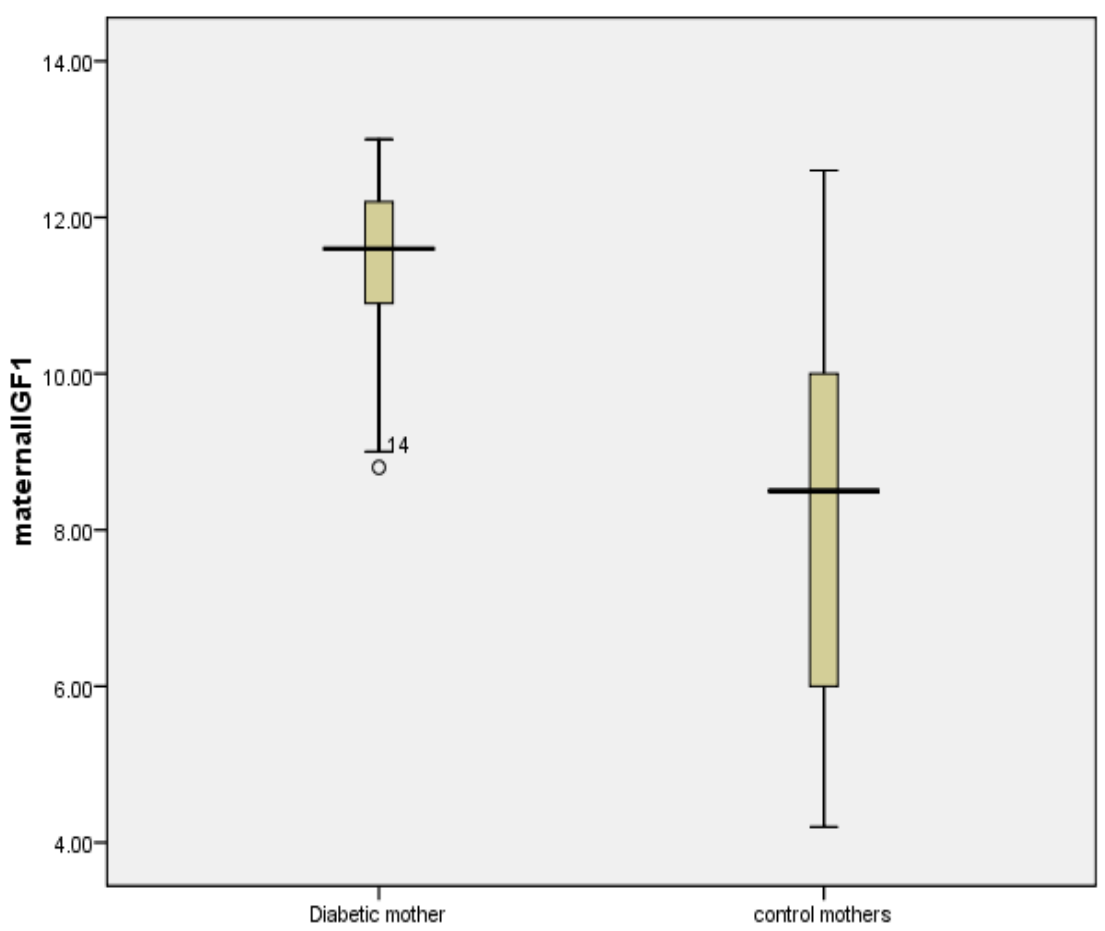

Figure 2: Box plot of the maternal IGF1 of the infants of the two studied groups.

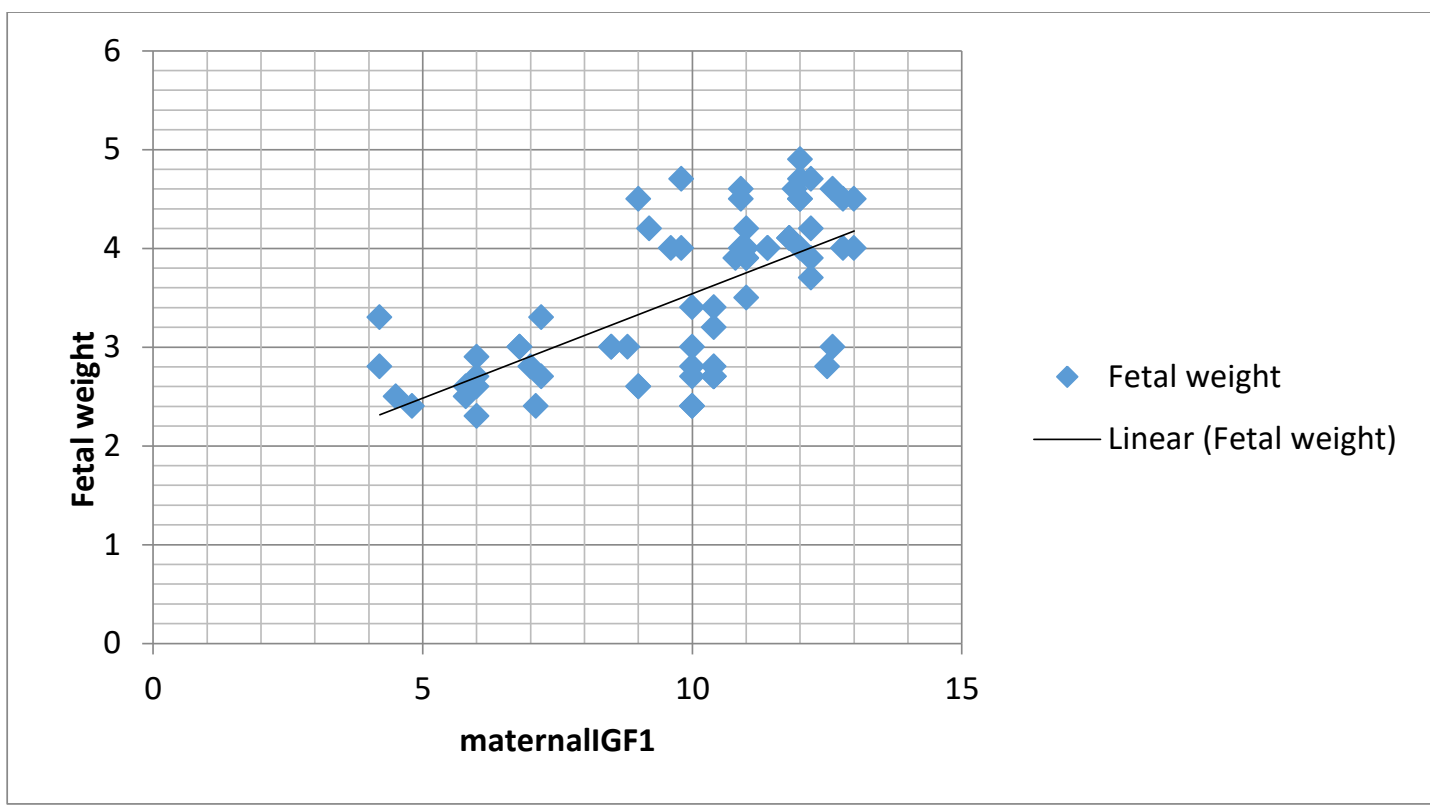

Figure 3 : Correlation between fetal weight and maternal IGF1.

Table4: linear regression between fetal weight and maternal IGF1 :

\begin{tabular}{|c|c|c|c|c|}
\hline \multirow[t]{2}{*}{ Variable } & \multicolumn{4}{|c|}{ fetal weight } \\
\hline & $\mathrm{B}$ & $\mathrm{SE}$ & Beta & Significance \\
\hline maternal IGF1 & 0.21 & 0.03 & 0.66 & $<0.001 * *$ \\
\hline
\end{tabular}


Table5: Risk assessment between diabetic and control mothers as regard fetal macrosomia.

\begin{tabular}{lllll}
\hline Risk factor & $\begin{array}{l}\text { Diabetic mothers } \\
\mathrm{n}=34\end{array}$ & $\begin{array}{l}\text { Control mothers } \\
\mathrm{n}=34\end{array}$ & $\begin{array}{l}\text { Odds ratio } \\
(95 \% \mathrm{CI})\end{array}$ & P value \\
\hline Fetal weight & & & 120 & $<0.001^{* * *}$ \\
Macrosomic $>3.5 \mathrm{~kg}$ & 32 & 4 & & \\
Average 2.5- $3.5 \mathrm{~kg}$ & 2 & 30 & & \\
\hline
\end{tabular}

Diabetic mothers are 120 times more likely to have macrosomic babies.

\section{DISCUSSION}

The most common medical complication of pregnancy is diabetes. It can affect up to $7 \%$ of all pregnancies. Insulin like growth factor1 "somatomedin C", is a protein manufactured in fibroblasts or other cells of mesenchymal origin, it has many mitogenic activities, including induction of cell growth, division, and differentiation. It also has an anabolic effect, enhancing glucose and amino acid uptake by cells and decreasing protein breakdown ${ }^{[6]}$. Macrosomia happens in about $12 \%$ of deliveries of healthy pregnancy \& 15 to $45 \%$ of deliveries of gestational diabetes affected mothers ${ }^{[2]}$. Consequences of macrosomia can affect both mothers and their children, during pregnancy, at birth, after birth and on the long run as well. Up till now diagnosis of macrosomia can only be done with prenatal ultrasonography with no specific lab test for such diagnosis. IGFI is not new to the medical field it has been discovered since the fifties of the last century, its relation to growth have been proven in the seventies as well. In this study we try to highlight its significant role and directly link it to neonatal macrosomia, in order to help further studies by providing a first step towards a diagnostic and may be one day a therapeutic approach. In our study we tried to find a proper test to diagnose macrosomic fetuses prenatally and to find the link between IGF1 and the outcome of babies of diabetic mothers regarding weight. We studied the level of IGF1 in serum of 68 pregnant women right before delivery. 34 women were known diabetics (we didn't give much consideration to their type of diabetes since it wouldn't affect the laboratory data by any mean but we did take detailed history from each mother in order to get good insight about their glycemic control during pregnancy) and the rest were healthy pregnant women as a control group.
The two groups were cohesive and has no significant difference according to age. according to the statistical analysis the mean age was $32.7 \pm 5.8$ with $\mathrm{T}$ test value -0.06 and $\mathrm{p}$ value was 0.9 (table1). Between the two mother groups the significant difference was noted regarding the laboratory testing for both random blood sugar and for insulin like growth factor 1 (table2) Mean random blood sugar in diabetic group was $241 \mathrm{mg} / \mathrm{dl}$ ranging from 130 to $400 \mathrm{mg} / \mathrm{dl}$. While; mean random blood sugar in control group was 109 $\mathrm{mg} / \mathrm{dl}$ ranging from 78 to $200 \mathrm{mg} / \mathrm{dl}$, with student $\mathrm{T}$ test 11.9 and $\mathrm{P}<0.001^{* *}$. Mean value of serum level of IGF1 in diabetic group founded to be $11.3 \mathrm{ng} / \mathrm{ml}$ with a range of 8.8 to $13 \mathrm{ng} / \mathrm{ml}$. In control group mean value of IGF1 $8.1 \mathrm{ng} / \mathrm{ml}$ ranging from 4.2 to $12.6 \mathrm{ng} / \mathrm{ml}$. with the student $\mathrm{T}$ test 7.1 and $\mathrm{P}$ value $<0.001^{* *}$ (table2) Higgins et al, 2012 found a great positive correlation between IGF1 levels in maternal blood of diabetic women with high glucose blood levels. IGFI was higher in diabetic mother's blood than its value in control mothers' blood [7] Gestational age according to our study varies in the two groups where in the control group the mean gestational age was 37.4 weeks ranging from 34 to 39 weeks of gestation $\mathrm{T}$ test -6.4 and $\mathrm{P}$ value $<0.001 * *$ with the fetal birth weight mean $2.8 \mathrm{~kg}$ varying from 2.3 to $3.4 \mathrm{~kg}$. While; in the case group the mean gestational age was 35 weeks with a mean fetal weight of $4.2 \mathrm{~kg}$ ranging from 3 to 4.9 $\mathrm{kg}$. (table3) (fig1) We found that with fetal macrosomia, babies are more likely to be delivered early with a mean gestational age of 35 weeks, (table3). Elisabeth R. Mathiesen, 2015 founded that there is higher prevalence of preterm deliveries associated with higher blood glucose levels and HBA1C levels in maternal blood in third trimester ${ }^{[8]}$. (Table4) 
shows that increased maternal IGF1 levels can predict fetal macrosomia by $44 \%$.

Hayati et al, 2004 shows that mothers with greatly raised IGFI concentrations at the time of delivery had macrosomic offspring's with neonatal, septal hypertrophic cardiomyopathy compared to control mothers ${ }^{[9]}$. Diabetic mothers are 120 fold more prone to have macrosomic babies, than non diabetic ones regardless their type of diabetes whether it is T1DM, T2DM or gestational diabetes. (table5) In a nation wide study; Ovesen et al, 2014 result was that GDM women had an increased risk of giving birth to a macrosomic neonate although the unadjusted analysis did not show any difference between the studied groups $^{[10]}$.

\section{CONCLUSIONS}

Insulin like growth factor 1 has higher levels than normal range in diabetic mothers' blood. Fetal macrosomia can cause a wide range of fetal complications as; hypoglycemia, hypocalcemia, hypomagnesiemia, respiratory distress and neonatal hypertrophic cardiomyopathy.

Fetal macrosomia can cause maternal complications as; Genital tract lacerations, bleeding after delivery, uterine rupture, cesarean section and preterm delivery.

Controlling blood glucose level during pregnancy is a corner stone for a healthy pregnancy and a healthy delivery.

Macrosomia can be predicted prenatally by measurement of maternal serum IGF1.

\section{REFERENCES}

1. Martin JA, Hamilton BE, Sutton PD, Ventura SJ, Menacker F, Kirmeyer S. Births: final data for 2004. Natl Vital Stat Rep. 2006, 55(1):1-101.

2. Jiangfeng Ye, Lin Zhang, Yan Chen, Fang Fang, ZhongCheng Luo, Jun Zhang:,
Searching for the definition of macrosomia through an outcome-based approach. PLoS ONE 2014, 9(6);e100192

3. Hermann GM, Dallas LM, Haskell SE, Roghair RD. Neonatal macrosomia is an independent risk factor for adult metabolic syndrome. Neonatology. $2010 ; 98: 238-44$

4. Faschingbauer F, Dammer U, Raabe E, et al. Sonographic weight estimation in fetal macrosomia: influence of the time interval between estimation and delivery. Arch Gynecol Obstet. 2014, dec 23

5. Kritzer S, Magner K, Warshak CR.. Increasing maternal body mass index and the accuracy of sonographic estimation of fetal weight near delivery. J Ultrasound Med. 2014, 33(12):2173-9

6. Turkalj I, Keller U, Ninnis R, Vosmeer S, Stauffacher W Effect of increasing doses of recombinant human insulin-like growth factor-I on glucose, lipid, and leucine metabolism in man. J Clin Endocrinol Metab. 1992, 75:1186- 1191

7. Higgins MF, Russell NE, Crossey PA, Nyhan $\mathrm{KC}$, Brazil DP, et al. Maternal and Fetal Placental Growth Hormone and IGF Axis in Type 1 Diabetic Pregnancy. PLoS ONE 2012 ,7(2): e29164. doi:10.1371

8. Elisabeth R. Mathiesen Pregnancy outcome in women with diabetes lessons learned from clinical research: The Norbert Freinkel Award Lecture Diabetes Care 2016;39:21112117 | DOI: 10.2337/dc16-1647 .

9. A R Hayati, F C Cheah, J F Yong, A E Tan, W M Norizah ,The role of serum insulin-like growth factor I (IGF-I) in neonatal outcome. 2004

10. Per Glud Ovesen,Dorte Møller Jensen,Peter Damm,Steen Rasmussen \&Ulrik Schiøler Kesmodel Maternal and neonatal outcomes in pregnancies complicated by gestational diabetes. a nation-wide study. The Journal of Maternal-Fetal \& Neonatal Medicine. (16 Apr 2014 